\title{
Using a Genre-Based Framework in Professional and ACademiC WRITING
}

\author{
Paula Gibson ${ }^{1}$; Pavlína Př́ibramská ${ }^{2}$ \\ ŠKODA AUTO University, Department of Languages and Intercultural Competences, \\ Na Karmeli 1457, 29301 Mladá Boleslav, Czech Republic \\ e-mail: ${ }^{1}$ paulagibson77@yahoo.co.uk; ${ }^{2}$ ypribramska@is.savs.cz
}

\begin{abstract}
The aim of the paper is to show how the application of genre-based frameworks, based on English for Specific Purposes (ESP) and Systemic Functional Linguistics (SFL) schools of genre, can be used in the teaching of professional and academic writing. Many students lack practical experience and that is way they have a poor awareness of professional writing as they have not yet been sufficiently exposed to work-place routines. Furthermore, they also struggle with their academic assignments in English. The paper will show how genre-based frameworks can be practically applied to teaching writing used in task instructions and as marking criteria.
\end{abstract}

\section{Introduction}

For the majority of language learners academic writing is an extremely difficult task [1], [2], [3]. This is mainly due to the fact that the texts the students are exposed to, for example text books and instructional materials, greatly differ from the written coursework that they have to write [4]. As a result, students have little understanding of the texts that they are expected to produce. Furthermore, students rarely see examples of other student's assignments that they could refer to in order to demystify writing expectations [5]. Therefore it could be argued that student writing is an occluded genre and learners need to understand how student genres are constructed.

The situation is even more difficult at institutes of higher education as students also receive conflicting instructions from both language tutors and academic specialists [2]. Therefore in order to combat this issue, an approach that incorporates both academic specialists and language teachers, would be highly beneficial to students [2], [6], [7]. Furthermore, in higher education there is no generic writing task that could be used across all disciplines [8], as they all have differing writing conventions [9], [10]. Therefore students need to have specific instructions in their chosen fields.

The application of genre theory is a useful tool resolving the above mentioned issues as it can allow learners to understand how their own discipline-specific discourse communities function [11], [12]. This allows students to identify how texts are structured on both microand macro levels. It also gives a rich description of the target language and incorporates the relationships within the discourse community [13], [14].

Based on the analysis presented above, this paper proposes a model which aims to resolve several key issues what instruction students need when writing for their academic subjects, by incorporating differing genre theories, academic experts and samples of student writing. 
There are three main schools of genre studies, however, this paper only focuses on the English for Specific Purposes (ESP) approach and the Systemic functional linguistics (SFL) approach. The former is based upon the work of John Swales who deals with the interaction of structure and linguistic features in scientific report writing. This was then further developed in EFL contexts to provide non-native speakers with the explicit features of discourse by identifying global organisational patterns through the analysis of structural moves in different discourse communities [15][16].

Although this approach is extremely insightful it only focuses on macro level structures and to this day has only been used in advanced academic and professional settings [1]. In addition, the content is hypothetical as it does not incorporate academic specialists [17]. However, this issue can easily be resolved by incorporating an academic specialist into the model.

SFL, on the other hand, is based on the research carried out by social semiotic linguist Michael Halliday, who states that genre is a tool to derive meaning from context [18]. This model was further refined by linguists and practitioners working together, notably [19], [20], [21], which means that the approach is the most pedagogically successful. Unlike ESP, SFL is built on the premise that students have to be explicitly taught lexical, grammatical and rhetorical features in order to be conscious of the relationships between content and meaning [22].

This approach was further expanded upon for usage in secondary schools and the work place by Rothery. The basis of this model is that as a more proficient interlocutor, the teacher deconstructs and reconstructs the target language in order to be conscious of the relationships between content and meaning, see Figure 1.

Source: [23]

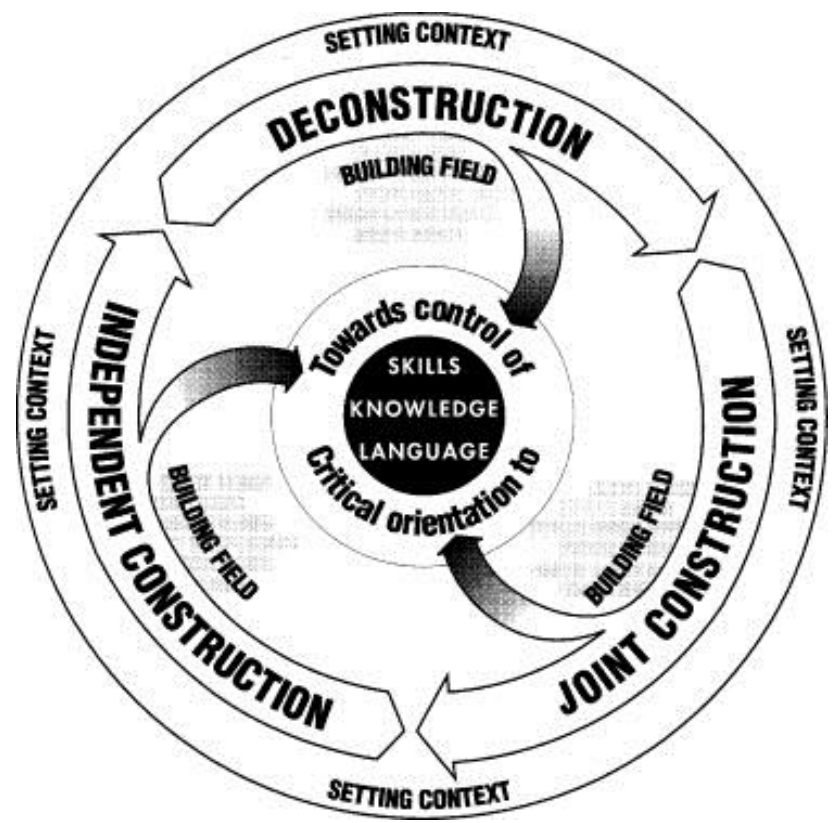

Fig. 1: Teaching / Learning cycle for mentoring genre

However, this model has been criticized for the lack of research on how this model can be used in institutes of higher education [22], [24], and this paper aims to show how SFL can overcome some of this criticism. 


\section{$2 \quad$ Methodology}

The research was undertaken using business and management master degree student's essays, as this is the main genre in their first-year course. In order to get a clear idea what support the students needed when writing, a need's analysis was carried out with an academic specialist, who has an excellent understanding of the conventions of the discourse community. Representative samples of student writing were analysed so that a clear understanding of the expected requirements in terms of content, language and structure and a clear set of study skills were determined, see Table 1 for a breakdown of the analysis.

Tab. 1: The results of the model discourse deconstruction

\begin{tabular}{|l|l|}
\hline Key elements & Deconstruction \\
\cline { 2 - 2 } & Finding source materials \\
& Identification of weighted sources \\
& Critical analysis \\
& Note taking \\
& Citing and referencing \\
& Paraphrasing and summarising \\
\hline Structure & Lead in / thesis / structure \\
& Theory \\
& Practical application \\
& Discussion \\
& Conclusion \\
\hline Language & Nominalisation \\
& Impersonal style \\
& Cohesion (referencing / ellipsis / substitution) \\
& Hedging \\
& Thematic patterning \\
& Formal style
\end{tabular}

Source: Own

Due to the complex nature of essay writing together with student's low awareness of the genre, it was concluded that this should be taught over the course of one semester $(2 \times 1.5$ hours per week for 14 weeks). At first, a sample student essay / model discourse was broken down in the class, so that students could identify the main elements. Since the model discourse has a lot of complex elements, the instruction was broken up into sections using both top-down and bottom-up approaches by a more expert interlocutor.

During the course of the semester students developed their awareness of the genre by being guided through the process of writing. Firstly, by finding suitable sources and reflecting on the suitability of each source. The students achieved this by giving a reflection on the article, who the author is, if they give weight to the argument, what the main principles are, how this relates to the business world, etc. As this was undertaken in class, all students could then use the evaluated sources for their own essay. These sources were then also used in practicing paraphrasing and summarising exercises.

In order to promote a good understanding of the practical application and discussion sections, collective brainstorming techniques were used and the students enhanced their argument skills by undertaking class debates. This allowed students to provide support for their arguments as the debate topics matched the main concepts of the reading sources. 
For the language section, all tasks were designed using the language from the core topics. The tasks were provided in class and for self-study on Moodle e-support. This also enabled learners to work on their own specific needs and at their own pace.

Students were then able to construct their own essays while being scaffolded by the interlocutor. Explicit feedback was provided for each essay based on the framework, which meant that students were able to understand the areas of concern and make changes accordingly. As a result, the exercises and explanations on Moodle became a toolkit for selfstudy.

\section{Conclusion}

This model has shown that the combination of applied linguistics, practitioners and academic specialists can provide a successful model of language structure and skills that students need. This method provides explicit instruction and allows students to identify their areas of weakness and also provides them with support on how to rectify these issues. In addition, the model could further be expanded upon using other genres such as business reports, case studies and feasibility studies.

Furthermore, this model could be used for any discourse, from presentations to business correspondence provided that you have a good text for analysis, and, if needed, are able to confer with a topic specialist in order to find genre specific salient features.

\section{Literature}

[1] JOHNS, A. M.: (2008). Genre awareness for the novice academic student: An on-going quest. Language Teaching. 41, 237-252.

[2] LEA, M.; STREET, B.: (1998). Student writing in higher education: An academic literacies approach. Studies in Higher Education. 23:2, 157 - 172.

[3] PALTRIDGE, B.: (2004). Academic writing. Language Teaching. Vol. 1(2): 87-105.

[4] NESI, H.; GARDNER, S.: (2006). 'Genres across the Disciplines: Student Writing in Higher Education. Cambridge University Press.

[5] LOUDERMILK, B.C.: (2007). Occluded academic genres: an analysis of the MBA thought essay. Journal of English for Academic Purposes. 6/3, 190-205.

[6] MORLEY, J.: (2008). Writing support in British higher education: An institutional case study. In: Friedrich P. (ed.) Teaching Academic Writing. London: Continuum, pp. 125146.

[7] WINGATE, U.: (2012). 'Argument!' helping students understand what essay writing is about. Journal of English for Academic Purposes. 11 (2012) 145 - 154.

[8] JOHNS, A.: (1997). Text, Role and Context: Developing Academic Literacies. Cambridge University Press.

[9] DUDLEY-EVANS, T.: (2002) The teaching of a problematic genre: The academic essay. In A. M. Johns (ed.), Genre in the classroom: Multiple Perspectives. Mahwah, NJ, Lawrence Erlbaum Publishers.

[10] PALTRIDGE, B.: (2002) Genre, text type and the EAP classroom. In A. Johns (ed.) Genre in the Classroom: Multiple Perspectives. Mahwah, NJ, Lawrence Erlbaum Publishers. 
[11] HYLAND, K.: (2007). Genre pedagogy: language, literacy and L2 writing instruction. Journal of Second Language Writing. Volume 16, issue 3, 148-164.

[12] SWALES, J.: (1990) Genre Analysis: English in Academic and Research Settings. Cambridge University Press.

[13] MARTIN, J. R.; ROSE, D.: (2007). (2 $2^{\text {nd }}$ ed.) Working with Discourse: Meaning Beyond the Clause. Bloomsbury Academic.

[14] JOHNS, A. M. (ed.): (2002). Genre in the Classroom: Multiple perspectives. Mahwah, NJ, Lawrence Erlbaum Publishers.

[15] BHATIA, V.: (1993). Analyzing Genre: Language use in Professional Settings. Longman.

[16] HYLAND, K.: (2004). Disciplinary interactions: metadiscoursal in L2 postgraduate writing. Journal of Second Language Writing. 13 (2004) 133-151.

[17] HYLAND, K.; HAMP-LYONS, L.: (2002). EAP: issues and directions. Journal of English for Academic Purposes. Vol 1. 1-12.

[18] HALlidAY, M. A. K.; MATHIESON, C. M. I. M.: (2004) An Introduction to Functional Grammar (3rd ed.). London, Hodder Arnold.

[19] MARTIN, J. R.: (1985). Factual writing: Exploring and Challenging Social Reality. Geelong, Deakin University.

[20] ROTHERY, J.: (1985). Writing to learn and learning to write. In J. R. Martin, Factual Writing: Exploring and Challenging Social Reality. Geelong, Deakin University.

[21] MARTIN, J. R.; CHRISTIE, F.; ROTHERY, J.: (1987). Social processes in education: A reply to Sawyer and Watson (and others). In I. Reid (ed.) The Place of Genre in Learning. (pp.58-82). Geelong, Centre for Studies in Literacy Education, Deakin University.

[22] MARTIN, J. R.: (2009). Genre and Language learning: A social semiotic perspective. Linguistics and Education. 20. 10-21.

[23] ROTHERY, J.: (1996). Making changes: Developing an educational linguistics. In J. R. Martin, Factual Writing: Exploring and Challenging Social Reality. Geelong, Deakin University.

[24] WOODWARD-KRON, R: (2005). The role of genre and embedded genres in tertiary students' writing. Prospect. Vol. 20. No 3 24-41.

BSc (hons) Paula Gibson M.A.; Mgr. Pavlína Př́ibramská 


\section{VYUŽITÍ ŽÁNRŮ V ODBORNÉM A AKADEMICKÉM PSANÍ}

Cílem tohoto článku je ukázat používání různých žánrů psaní, vytvořených pro anglický jazyk pro zvláštní účely (ESP) a systémovou funkční lingvistiku (SFL). Tyto mohou být aplikovány ve výuce odborných předmětů a předmětu akademického psaní. $Z$ důvodu nedostatku praktických zkušeností, mají mnozí studenti malé povědomí o obchodní korespondenci, protože dosud nebyli dostatečně obeznámeni s pracovním prostředím. Kromě toho se také potýkají s různými písemnými úkoly při studiu na vysoké škole v anglickém jazyce. Autoři ukazují, jak lze jednotlivé žánry prakticky aplikovat ve výuce psaní.

\section{NUTZUNG DER GENRES IM FACHSPRACHLICHEN UND AKADEMISCHEN SCHREIBEN}

Ziel dieses Artikels ist das Aufzeigen verschiedener Genres des Schreibens, wie sie für die englische Sprache für besondere Zwecke (ESP) und die systemfunktionelle Linguistik (SFL) begründet sind. Diese können im Fachunterricht und im Unterricht des akademischen Schreibens Anwendung finden. Da es meist an praktischen Erfahrungen fehlt, besitzen die Studenten schlechte Kenntnisse über Handelskorrespondenz, weil sie bislang mit dem Arbeitsmilieu nicht vertraut sind. Zudem habe sie es an der Hochschule mit verschiedenen schriftlichen Aufgaben im Englischen zu tun. Die Autoren zeigen, wie man einzelne Genres im Schreibunterricht praktisch anwenden kann.

\section{WYKORZYSTANIE RÓŻNYCH GATUNKÓW PISARSKICH W SPECJALISTYCZNYM I AKADEMICKIM JĘZYKU PISANYM}

Celem niniejszego artykułu jest pokazanie stosowania różnych gatunków pisarskich, opartych na języku angielskim dla celów specjalistycznych (ESP) i lingwistyce systemowofunkcjonalnej (SFL), które mogą mieć zastosowanie w nauczaniu przedmiotów specjalistycznych oraz przedmiotu Pisanie akademickie. W związku z brakiem doświadczeń praktycznych wielu studentów posiada złą wiedzę w zakresie korespondencji handlowej, ponieważ nie zostali w wystarczający sposób zapoznani ze środowiskiem pracy. Trudności sprawiają im także różne zadania pisemne w czasie zajęć uczelnianych prowadzonych $\mathrm{w}$ języku angielskim. W opracowaniu wskazano, w jaki sposób poszczególne gatunki można praktycznie zastosować w nauczaniu pisania. 